\title{
RELATIONSHIP BETWEEN MERCURY CONCENTRATION IN WATER, BOTTOM SEDIMENT AND TWO MOLLUSC SPECIES (CRASSOSTREA GASAR AND TYMPANOTONUS FUSCATUS) FROM A LAGOS CREEK IN NIGERIA
}

\author{
AO Lawal-Are ${ }^{1}$, RO Moruf ${ }^{*}$, UJ Sobara ${ }^{1}$ and KB Salami ${ }^{1}$ \\ ${ }^{1}$ Department of Marine Sciences, University of Lagos, Akoka, Lagos State, Nigeria \\ ${ }^{2}$ Department of Fisheries and Aquaculture, Bayero University, Kano, Kano State, Nigeria
}

\begin{abstract}
Concentration of mercury was investigated in the flesh and shell of two species of benthic mollusc, Crassostrea gasar and Tympanotonus fuscatus and in water and sediment from Makoko Creek, adjacent to the Lagos Lagoon between January to September 2019. Values obtained for physicochemical parameters in Makoko Creek (water temperature- $28.92 \pm 0.1^{\circ} \mathrm{C}$; $\mathrm{pH}-7.73 \pm 0.02$; salinity$14.23 \pm 0.05 \mathrm{ppt}$; dissolved oxygen- $5.34 \pm 0.02 \mathrm{mg} / \mathrm{l}$; biological oxygen demand- $7.780 \pm 0.1 \mathrm{mg} / \mathrm{l}$ and chemical oxygen demand- $12.34 \pm 0.02 \mathrm{mg} / \mathrm{l}$ ) were within the acceptable levels for survival, metabolism and physiology of aquatic organism. The concentration of mercury followed decreasing order as sediment >water >flesh >shell across locations for both species. For all the tested samples of $C$. gasar and $T$. fuscatus, biowater accumulation factor in flesh and shell were higher than those of bio-sediment accumulation factor. The coefficients of variance (CV \%) in shells were lower than those of the flesh for both investigated mollusc species. It was shown that mercury contents of flesh or shells of $C$. gasar and T. fuscatu are directly affected by those of water and bottom sediment.
\end{abstract}

Key words: Crassostrea gasar, Lagos Lagoon, Mercury, Periwinkle, Tympanotonus fuscatus

\section{Introduction}

The contamination of aquatic ecosystem by heavy metals can persist for many years in sediments, where they hold the potential to affect aquatic biota and poses considerable environmental risks and concerns. Mercury, a nonessential metal naturally occurs in the environment as a result of volcanic degassing of the Earth's crust and weathering of mercury rich geology (Yin et al. 2013). While water from areas rich in mercury ores may exhibit high local mercury concentrations, industrial processes, agriculture and the combustion of fossil fuel are the most significant sources of aquatic contamination (Khoei and Bastami 2013). Mercury has no necessary function in living organism and is among the most toxic elements to man and many higher animals. Common sources include caustic soda, pulp and paper, batteries, dental amalgam, bactericides, paint manufacturing etc. As for most metals, factors known to influence mercury concentrations and accumulation in the marine organisms include metal bioavailability, season of sampling, hydrodynamics of the environment, size, sex and changes in tissue composition and reproductive cycle (Hosseini et al. 2012).

Sediments are important sinks for various pollutants and play a useful role in the assessment of heavy metal contamination (Delshab et al. 2017). According to Salas et al. (2017), bottom sediments may serve as a metal pool that can release metals to the overlaying water via natural anthropogenic processes, causing

*Author for correspondence: tunjimoruf@gmail.com 
potential adverse health effects to the ecosystems because of their serious toxicity and persistence. The deposition of mercury in sediments occurs through an interaction between sediment and water, whereby variations of metal contents of sediment and water depend on variation of water chemistry, for example temperature, $\mathrm{pH}$ and solute concentration (Hosseini et al. 2012). Accumulation of heavy metals only begins after the organisms are faced with high concentration in the surrounding medium, but body levels of nonessential metals such as mercury were not found to be regulated by invertebrate (Khoei and Bastami 2013).

The analyses of water or sediment samples, however, are subject to a variety of shortcomings, in that the methods do not allow for the estimation of the quantity of the metal, which is biologically available (Prata et al. 2019). It is against this background that bio-indicators are preferred in environmental monitoring. Molluscs are effective biomonitors and have been widely used for heavy metal monitoring purposes worldwide (Obirikorang et al. 2010, El-Sorogy and Attiah 2015, Abdel-Ghany 2017, Mohammad et al. 2017, Heiba et al. 2019, Usese et al. 2019). They reflect traces of contamination better than finfishes because they are sediment dwelling and have pronounced ability to concentrate pollutants from sediments and water (McCaffrey et al. 2017). Oyster (C. gasar) and periwinkle (T. fuscatus) are benthic molluscs which are highly popular, nutritious and commercially available in southern parts of Nigeria. They are relatively cheap source of animal protein and the shells have been affirmed as good feedstuff in animal feed formulation (Moruf and Akinjogunla 2018). This study was conducted to examine the levels of mercury in flesh and shell of two species of benthic mollusc, C. gasar (Adanson 1757) and T. fuscatus (Linnaeus 1758), and to ascertain relations to water and sediment of Makoko Creek in Lagos, Nigeria.

\section{Materials and Methods}

\section{Study site}

The Makoko Creek (Fig. 1) in Lagos, is a micro tidal creek that drains into the Lagos Lagoon from the western part. It lies between Latitude N06 ${ }^{\circ} 29^{\prime} 41.1^{\prime \prime}$ and Longitude E03 $23^{\prime} 43.3^{\prime \prime}$ (Adejumobi et al. 2019). It has a sandy bottom with misty water due to serious anthropogenic activities. The creek is situated in Makoko community, a small fishing municipal on the coast of Lagos mainland in Nigeria.

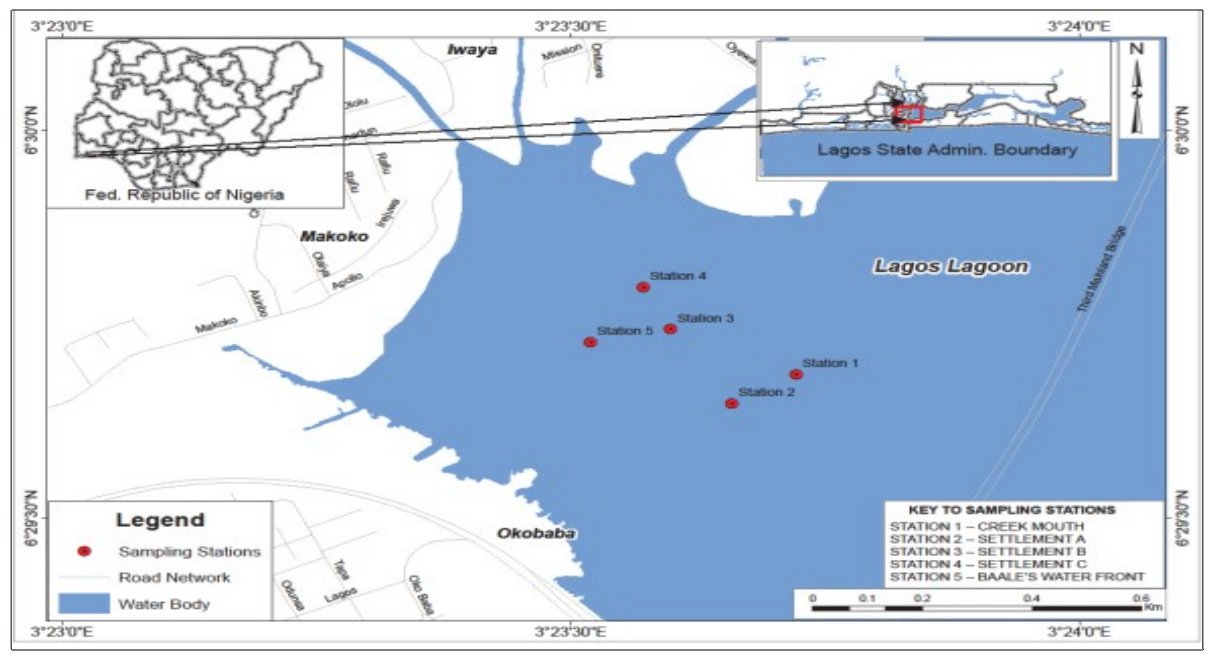

Fig. 1: Map of the Lagos Lagoon showing sampling stations (Adejumobi et al. 2019). 


\section{Sample collection}

Water and sediment samples scooped from the Makoko Creek were collected into $70 \mathrm{ml}$ plastic bottles and polythene bags respectively. To prevent adsorption of metals into the walls of the containers, the samples were acidified with 2 drops of concentrated $\mathrm{HNO}_{3}$ (APHA 2005) and stored in a refrigerator at temperature of $4^{\circ} \mathrm{C}$ while the sediments in polythene bags were stored at $0^{\circ} \mathrm{C}$ in a refrigerator before analysis. Monthly measurement of water temperature, salinity, $\mathrm{pH}$, dissolved oxygen, biological oxygen demand and chemical oxygen demand of both creeks were taken for the period using a Hanna (HI-9028) multiparameter probe.

Samples of two benthic mollusc, C. gasar and T. fuscatus were collected by scooping from the waterbed at low tides and dislodgement from mangrove branches and roots, from January to September 2019. The sampling was carried out at the early hours of each day, thrice a week for the period of sampling. Twelve replicates of samples were used for analysis in this study.

\section{Laboratory analysis}

Mercury concentrations were analysed on digested water and sediment slurry samples according to the cold vapor method using a Perkin-Elmer Atomic Absorption System AA-2380 with automatic background correction and a Perkin-Elmer Mercury Analysis System 303-0830 as described by Khoei and Bastami (2013). After depurating the mollusc samples, a sterile stainless steel knife was used to dislodge and remove the soft tissue of each mollusc from the shell (Chiu et al. 2000). Both the flesh and the shell were then separately dried in an oven at $105^{\circ} \mathrm{C}$ until constant weight was obtained and later separately homogenized using mortar and pestle. $10 \mathrm{~g}$ of each homogenate was separately digested as described by APHA (2005). The completely digested subsamples were allowed to cool at room temperature, and the undigested portions were filtered off through a Whatmann Glass Microfibre filter paper (GF/C) to obtain a clear solution and diluted to $50 \mathrm{ml}$ in volumetric flasks with double distilled water (Otchere 2003). The Atomic Mercury Analyzer (Model HG 5000) equipped with a mercury lamp at a wavelength $253.7 \mathrm{~nm}$ was used for the determination of total mercury in the mollusc samples as described by Obirikorang et al. (2010).

Bioaccumulation factor was calculated according to Usero et al. (2005), to assess the accumulation level of mercury in the mollusc tissues as follows:

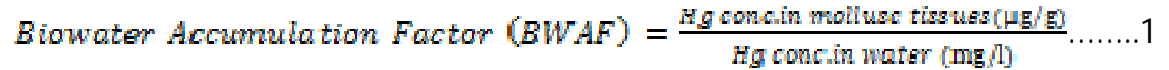

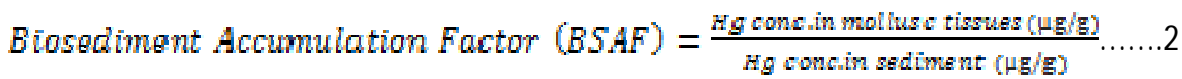

The degree of variability of mercury levels in the mollusc tissues determined (Yap et al. 2003) by

$$
\text { Coefficient of variation }(C V \%)=\frac{\text { standard deviation } x 100}{\text { Mean }} \ldots \ldots . . .3
$$

\section{Statistical analysis}

Results of the mercury analyses were subjected to Pearson Correlation Analysis (PCA) to test for significant relation in the concentrations of mercury among the four samples. The result was analyzed using Microsoft Excel and STAT 7.0 statistical package. 


\section{Results}

\section{Physico-chemical parameters of Makoko Creek}

The summary of the physico-chemical variables is shown in Table 1. Recorded values for water temperature varied from $25.40^{\circ} \mathrm{C}$ to $30.43^{\circ} \mathrm{C}$, with a mean value of $28.92^{\circ} \mathrm{C}$. The $\mathrm{pH}$ and Salinity values were $7.73 \pm 0.02$ and $14.23 \pm 0.05 \mathrm{ppt}$ respectively. The high $\mathrm{pH}$ value obtained may be related to the growth of algae population, aquatic vegetation and photosynthetic activity, which increase total alkalinity. Similarly, high dissolved oxygen $(5.34 \pm 0.02 \mathrm{mg} / \mathrm{l})$, biological oxygen demand $(7.780 \pm 0.1 \mathrm{mg} / \mathrm{l})$ and chemical oxygen demand $(12.34 \pm 0.02 \mathrm{mg} / \mathrm{l})$ were recorded in the creek.

Table 1. Physicochemical parameters of a micro tidal creek in Lagos, Nigeria

\begin{tabular}{llcc}
\hline Sampling area & \multicolumn{1}{c}{ Parameters } & Range & Mean \pm SD \\
\hline & Water temperature $\left({ }^{\circ} \mathrm{C}\right)$ & $25.40-30.43$ & $28.92 \pm 0.1$ \\
& pH at 25 & $7.69-8.57$ & $7.73 \pm 0.02$ \\
& Salinity (ppt) & $12.43-16.62$ & $14.23 \pm 0.05$ \\
Makoko Creek & Dissolved oxygen $(\mathrm{mg} / \mathrm{l})$ & $5.13-5.27$ & $5.34 \pm 0.02$ \\
& Biological oxygen demand $(\mathrm{mg} / \mathrm{l})$ & $6.33-8.67$ & $7.780 \pm 0.1$ \\
& Chemical oxygen demand $(\mathrm{mg} / \mathrm{l})$ & $9.00-15.67$ & $12.34 \pm 0.02$ \\
\hline
\end{tabular}

$\mathrm{SD}=$ Standard deviation

\section{Concentration of mercury in water and sediment}

The mean values of mercury concentration in water and sediment samples from Makoko Creek as shown in Fig. 2 and 3 were $0.40 \mathrm{mg} / \mathrm{l}$ and $0.68 \mu \mathrm{g} / \mathrm{g}$, respectively. Station 3 has the highest mercury concentration both in water and in bottom sediment. However, significant difference could not be established as seen from the value overlap.

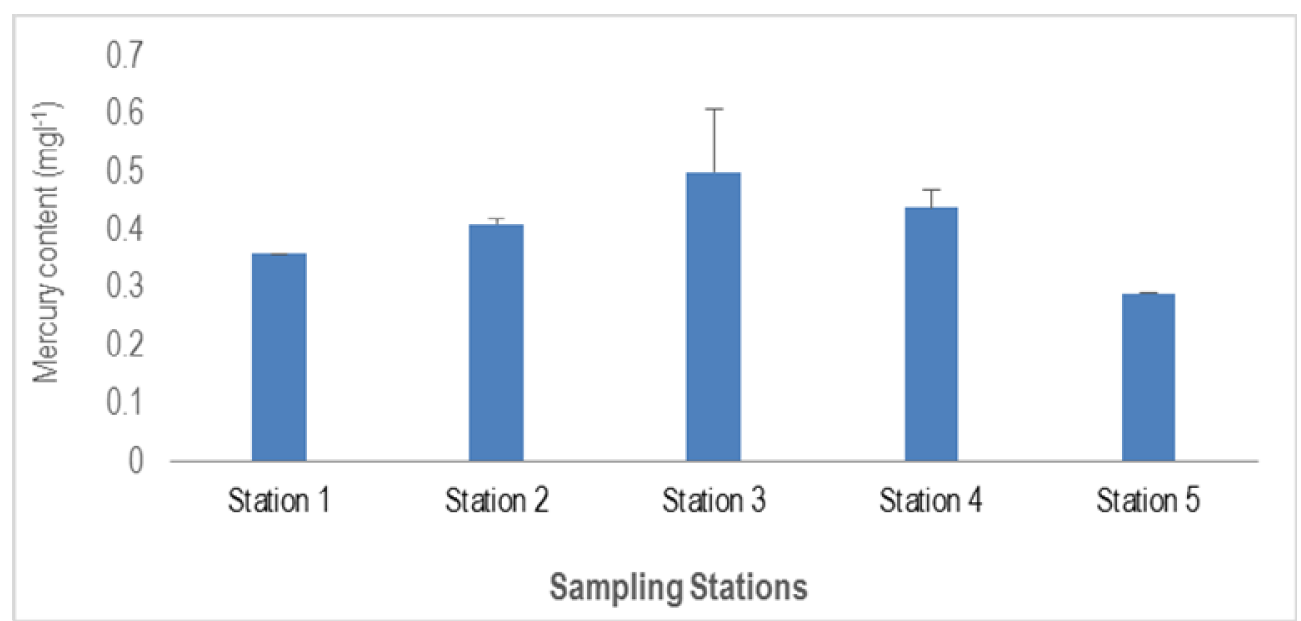

Fig. 2: Mercury concentrations in water (mg/l) of Makoko Creek in Lagos, Nigeria. 


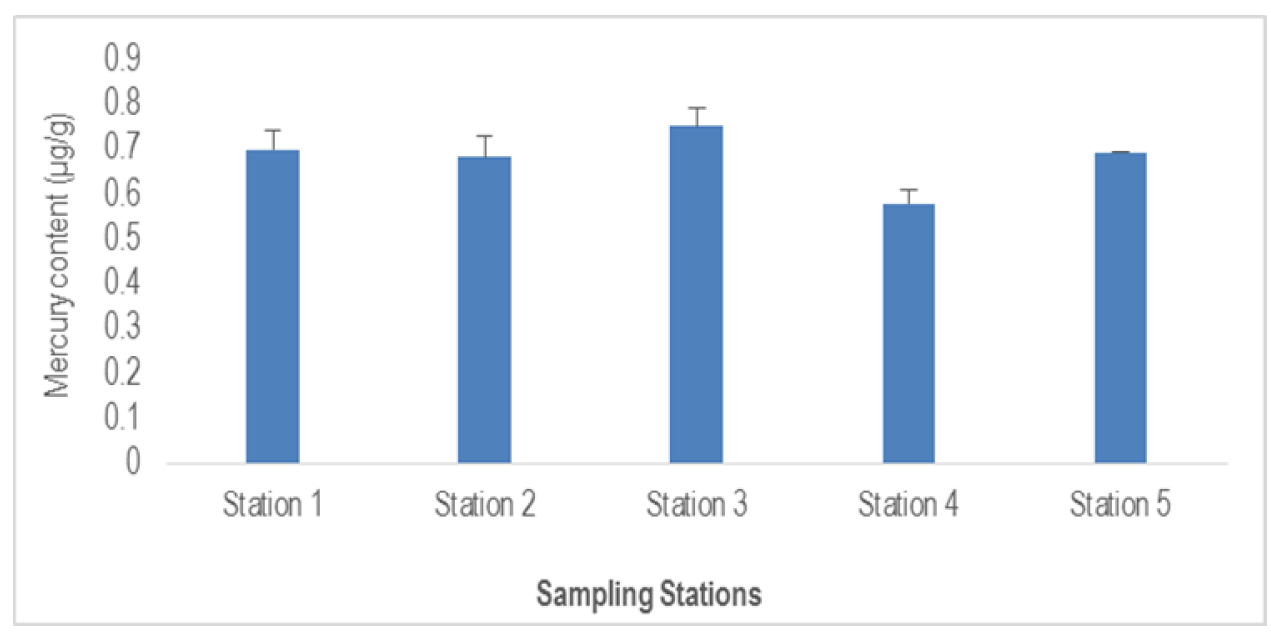

Fig. 3. Mercury concentrations in bottom sediment $(\mu \mathrm{g} / \mathrm{g})$ of Makoko Creek in Lagos, Nigeria.

\section{Concentration of mercury in benthic mollusc species}

Table 2 presents the results of mercury concentration in C. gasar and T. fuscatus from Makoko Creek. Higher mercury content $(\mu \mathrm{g} / \mathrm{g})$ was recorded in $T$. fuscatus (flesh: 0.42 , shell: 0.34 ) than in $C$. gasar (flesh: 0.37, Shell: 0.28). In both species, mercury was more accumulated in the flesh than in the shell. Heterogeneous relationship of mercury concentration in flesh and shell was more pronounced in C. gasar than in T. fuscatus with 19.58 and 14.89 co-efficient of variation per cent, respectively.

Table 2. Mercury centration $(\mu \mathrm{g} / \mathrm{g})$ in two species of mollusc from Makoko Creek in Lagos, Nigeria

\begin{tabular}{lccccccc}
\hline Species & Flesh & Shell & Mean & SD & CV (\%) & Flesh-Shell & $\%$ of Diff. \\
\hline C. gasar & 0.37 & 0.28 & 0.33 & 0.06 & 19.58 & 0.09 & 24.32 \\
T. fuscatus & 0.42 & 0.34 & 0.38 & 0.06 & 14.89 & 0.08 & 19.05 \\
\hline
\end{tabular}

\section{Bioaccumulation efficiency of mercury}

Bio-water accumulation factor (BWAF) and bio-sediment accumulation factor (BSAF) of mercury in C. gasar and $T$. fuscatus are shown in Table 3. BWAF values in flesh and shell were higher than those of BSAF for both species. Greater heterogeneous relationship was recorded between the BWAF and BSAF of $C$. gasar than in T. fuscatus both in flesh and shell. 
Table 3. Bioaccumulation efficiency and co-efficient of variation (CV\%) values of the flesh and shell of two species of mollusc from Makoko Creek in Lagos, Nigeria

\begin{tabular}{lcccccc}
\hline \multirow{2}{*}{ Mollusc } & \multicolumn{2}{c}{ Bio-water accumulation factor } & \multicolumn{2}{c}{ Bio-sediment accumulation factor } & \multicolumn{2}{c}{ Coefficient of variation } \\
\cline { 2 - 7 } & Flesh & Shell & Flesh & Shell & Flesh & Shell \\
\hline C. gasar & 0.93 & 0.70 & 0.54 & 0.41 & 37.52 & 36.95 \\
T. fuscatus & 1.05 & 0.85 & 0.62 & 0.50 & 36.41 & 36.66 \\
\hline
\end{tabular}

\section{Relationship between mercury content in water, sediment and mollusc tissues}

Relationships among concentrations of mercury in water, sediment and the molluscs (flesh and shell) from Makoko Creek were recorded in Table 4 and 5. For $C$. gasar, there is a positive correlation (0.756) between the flesh and the sediment; and positive correlation $(0.936)$ was observed between shell and water. A disimilar results were recorded for $T$. fuscatus in Table 5 , where positive relationships exist between flesh and water (0.999) and between shell and sediment (0.693).

Table 4. Relations between the mercury concentrations in water, sediment and those in the flesh and shell of a benthic bivalve, C. gasar from Makoko Creek in Lagos, Nigeria

\begin{tabular}{lcccc}
\hline & Water & Sediment & Flesh & Shell \\
\hline Water & 1 & & & \\
Sediment & -0.997 & 1 & & \\
Flesh & -0.807 & 0.756 & 1 & 1 \\
Shell & 0.936 & -0.904 & -0.963 & 1 \\
\hline
\end{tabular}

Table 5. Relations between the mercury concentrations in water, sediment and those in the flesh and shell of a benthic gastropod, Tympanotonus fuscatus from Makoko Creek in Lagos, Nigeria

\begin{tabular}{lcccc}
\hline & Water & Sediment & Flesh & Shell \\
\hline Water & 1 & & & \\
Sediment & -0.997 & 1 & & \\
Flesh & 0.999 & -0.997 & 1 & 1 \\
Shell & -0.750 & 0.693 & -0.750 & 1 \\
\hline
\end{tabular}

\section{Discussion}

Values obtained for physico-chemical parameters in Makoko Creek were within the acceptable levels for survival, metabolism and physiology of aquatic organism as affirmed from WHO (2004). The temperature range in the present study was within the tropical climate range of $\angle 40^{\circ} \mathrm{C}$ for coastal waters as stated by FMENV (2001). The decrease or increase in water temperature depends mainly on the climatic conditions, 
sampling times, sunshine hours and affected by specific characteristics of water environment such as turbidity, wind force, plant cover and humidity (Ahmed et al. 2017). Hydrogen ion concentration (pH) is the master control parameter in aquatic environment for the chemical and biological transformation of water. The $\mathrm{pH}$ values in the studied creek were in alkaline side at all sites, with similar report by Nkwoji (2016) who obtained minimum $\mathrm{pH}$ of 7.17 , mean $\mathrm{pH} 7.8 \pm 0.3$ and maximum of 8.7 while assessing quality of Makoko water. The recorded values for salinity, dissolved oxygen, biological oxygen demand and chemical oxygen demand in the present study are higher than the results of Lawal-Are et al. (2019) who reported mean salinity of $11.1 \pm 3.2 \mathrm{ppt}$, dissolved oxygen of $5.3 \pm 0.1 \mathrm{mg} / \mathrm{l}$, biological oxygen demand of $5.1 \pm 0.6 \mathrm{mg} / \mathrm{l}$ and chemical oxygen demand of $19.0 \pm 3.9 \mathrm{mg} / \mathrm{l}$ for Abule-Eledu Creek.

In the present study, the concentration of mercury followed decreasing order as sediment >water $>$ flesh $>$ shell across location for both species. According to Moruf and Akinjogunla (2019), sediment serves a major depository of metals holding more concentrations that water. The analysis of the mollusc tissues showed that higher levels of mercury were present in the flesh than in the shell of both species. This is similar to the findings of Obirikorang et al. (2010) where significant higher mercury concentration in the soft tissue of bottom-feeding bivalvia species was reported. Metals' accumulation in sediment and water gives a chance for some aquatic organisms to bio accumulate metals and transport them via the food chain. Consequently, this agrees with Khoei and Bastami (2013) who are of the view that nearly the entire mercury burden in benthic organism is from their diets.

For all the tested samples of $C$. gasar and $T$. fuscatus, BWAF values in flesh and shell were higher than those of BSAF. This agrees with results of El-Khayat et al. (2015) and Gawad (2018). Such species have the potentials to be widely used for water biomonitoring. Metal concentrations in benthic mollusc differ from one species to the other due to the specific ability of each to regulate this metal, and according to Jung and Byeong (2005), this has been attributed to the physiology of digestion of species and the rate of absorption of the metal (Jung and Byeong 2005). The coefficients of variance (CV\%) in shells were lower than those of the flesh for both investigated mollusc species. This agrees with Gawad (2018) who mentioned that soft tissue metal levels could be affected by the physiological processes of the mollusc, while the concentration in the shell could hardly be affected by these physiological conditions.

Correlation results showed significant direct relations among the concentrations of mercury in these specimens. This agrees with Mahmoud and Taleb (2013) who recorded that accumulation of some heavy metals in tissues of snails were directly proportional with metal concentrations in water in which these snails live.

\section{Conclusion}

Generally, higher mercury concentration was recorded in sediment than in water, possibly due to the settling ability of the metal and the inability of the water to retain mercury because of its metal density. Mercury concentrations in benthic mollusc differ from one species to the other due to the specific ability of each to regulate or accumulate this metal. For all the tested specimens, BWAF values in shell and soft tissue were higher than those of BSAF. These species have good potentials to be used for water biomonitoring. Higher CV\% values and higher concentrations of mercury in flesh, than those found in shell, did not strongly support the usefulness of shells as bio-indicators for mercury rather soft tissues will be more effective in monitoring mercury level. It was shown that mercury contents of flesh or shells of $C$. gasar and $T$. fuscatu are directly affected by those of water and bottom sediment. 


\section{References}

Abdel-Ghany SR (2017). Heavy metals bioaccumulation in the edible bivalvia Venerupis decussata collected from Port Said, Egypt. Wulfenia J. 24(5): 48-62.

Adejumobi KO, Nwankwo DI and Adedipe J (2019). Environmental characteristics, plankton diversity and seasonal variation at the Makoko Creek. International Journal of Fisheries and Aquatic Studies, 7(3): 203-212.

Ahmed MH, El-Hamed A, Nadia NB and Shalby NI (2017). Impact of physico-chemical parameters on composition and diversity of zooplankton community in Nozha hydrodrome, Alexandria, Egypt. Egyptian Journal of Aquatic Biology and Fisheries, 21(1): 49-62.

APHA (2005). Standard Methods for the Examination of Water and Wastewater. 22nd Edition, American Public Health Association, Washington DC, USA.

Chiu ST, Lam FS, Tze W, Chau CW and Ye DY (2000). Trace metals in mussel from mariculture zones, Hong Kong. Chemosphere, 41: 101-108.

Delshab H, Farshchi P and Keshavarzi B (2017). Geochemical distribution, fractionation and contamination assessment of heavy metals in marine sediments of the Asaluyeh port, Persian Gulf. Marine Pollution Bulletin, 115(1-2): 401411.

El-Khayat HMM, Mahmoud KMA, Gaber HS, Abdel-Hamid H and Taleb HMA (2015). Studies on the effect of pollution on Lake Manzala ecosystem in Port- Said, Damietta and Dakahlia Governorates, Egypt. J. Egypt. Soc. Parasitol., 45(1): 155-168.

El-Sorogy AS and Attiah A (2015). Assessment of metal contamination in coastal sediments, seawaters and bivalves of the Mediterranean Sea coast. Egypt. Mar. Pollut. Bull., 101(2): 867-871.

FMENV (Federal Ministry of Environment) (2001). National guidelines and standards for water quality in Nigeria. Technical Advisory Committee on Water Quality Criteria, Federal Ministry of Environment, Abuja, Nigeria, pp. 114.

Gawad SSA (2018). Concentrations of heavy metals in water, sediment and mollusk gastropod, Lanistes carinatus from Lake Manzala, Egypt. The Egyptian Journal of Aquatic Research, 44(2): 77-82.

Heiba FN, Nassef MN and Mona MM (2019). Seasonal variations of heavy metals levels in Sea water, sediment, and soft parts of edible bivalve Donax trunculus from Port Said coast, Egypt. Egypt. J. Exp. Biol. (Zool.), 15(2): 191-199.

Hosseini M, Bastami AA, Khoei JK, Esmailian M, Songhori, EJ and Najafzadeh M (2012). Concentrations of heavy metals in selected tissues of blue swimming crab, Portunus pelagicus (Linnaeus 1758) and sediments from Persian Gulf. World Applied Sciences Journal, 19(10): 1398-1405.

Jung SL and Byeong GL, (2005). Effects of salinity, temperature and food type on the uptake and elimination rates of $\mathrm{Cd}$, $\mathrm{Cr}$, and $\mathrm{Zn}$ in the Asiatic Clam Corbicula fluminea. Ocean Sci. J. 40(2): 79-89.

Khoei JK and Bastami AA (2013). Mercury concentrations in tissues of blue swimming crab Portunus pelagicus and sediments from Khark Island. World Applied Sciences Journal, 21(9): 1391-1397.

Lawal-Are AO, Moruf RO, Amosu Al and Sadiq SO (2019). Dynamics of crustacean larvae composition and abundance in mesohaline creeks of Lagos Lagoon, Nigeria. Egyptian Academic Journal of. Biological Sciences B. Zoology 11(2): 99- 110.

Mahmoud KMA and Taleb HMA (2013). Fresh water snails as bio-indicator for some heavy metals in the aquatic environment. Afr. J. Ecol., 51: 193-198.

McCaffrey SC, Murray JS and Woodhouse M (2017). Early work: marine biology and pollution. in promoting equity, cooperation and innovation in the fields of transboundary Waters and Natural Resources Management, Brill Nijhoff., pp. 10-50. 
Mohammad S, Ibrahim R and Mohamed S (2017). Heavy metals and some nutritional elements in the Mediterranean carpet shell clam Donax semistriatus. Indian J. Geo Mar. Sci., 46(06): 1145-1154.

Moruf RO and Akinjogunla VF (2018). Photometric determination of macro-micro minerals in the West African Mud Creeper, Tympanotonus fuscatus var. radula (Linnaeus, 1758). Journal of Experimental Research, 6(3): 35-40.

Moruf RO and Akinjogunla VF (2019). Concentration of heavy metals in sediment of two interconnecting brackish/freshwater lagoons and the bioaccumulation in the crustacean, Farfantepenaeus notialis (Pérez-Farfante, 1967). Journal of Fisheries and Environment, 43(3): 55-62.

Nkwoji JA (2016). Impact of hypoxia on the community structure of benthic macroinvertebrates of Lagos Lagoon, Nigeria. J. Appl. Sci. Environ. Manage., 20 (1): 121-130.

Obirikorang KA, Amisah S, Adjei-Boateng D, Madkour HA and Otchere FA (2010). Mercury accumulation in the clam, Galatea paradoxa (Born 1778) at the Volta Estuary, Ghana. Bulletin of Environmental Contamination and Toxicology, 85(5): 497-501.

Otchere FA (2003). Heavy metals concentrations and burden in the bivalves (Anadara senilis, Crassostrea tulipa and Perna perna) from lagoons in Ghana: model to describe mechanism of accumulation/excretion. Afr J. Biotechnol., 2(9): 280-287.

Prata JC, Da Costa JP, Duarte AC and Rocha-Santos T (2019). Methods for sampling and detection of microplastics in water and sediment: a critical review. Trends in Analytical Chemistry, 110: 150-159.

Salas PM, Sujatha $\mathrm{CH}$, Kumar CR and Cheriyan E (2017). Heavy metal distribution and contamination status in the sedimentary environment of Cochin estuary. Marine Pollution Bulletin, 119(2): 191-203.

Usero J, Marilla J and Graccia I (2005). Heavy metal concentrations in mollusc from the Atlantic Coast of Sothern Spain. Chemosphere 59: 1175-1181.

Usese Al, Elike El, Moruf RO and Chukwu LO (2019). Levels of oxidative stress markers in the mangrove oyster, Crassostrea gasar from a coastal ecosystem in Southwest Nigeria. Journal of Research in Forestry, Wildlife \& Environment 11(1): 32-38.

WHO (2004). Guideline for drinking water quality Recommendations Vol. $13^{\text {rd }}$ edition, WHO Geneva.

Yap CK, Ismail A, Tan SG and Abdul Rahim I (2003). Can the shell of the greenlipped mussel Perna viridis from the west coast of Peninsular Malaysia be a potential biomonitoring material for $\mathrm{Cd}, \mathrm{Pb}$ and $\mathrm{Zn}$ ? Estuarine, Coast. Shelf Sci., 57: $623-630$.

Yin R, Feng X, Wang J, Li P, Liu J, Zhang, Y and Hu T (2013). Mercury speciation and mercury isotope fractionation during ore roasting process and their implication to source identification of downstream sediment in the Wanshan mercury mining area, SW China. Chemical Geology, 336: 72-79. 